\title{
溶接後熱処理による熱履歴が鋼部材の 応力緩和および変形挙動に及ぼす影響
}

\author{
森＼cjkstart博啓 1 ・廣畑 幹人 2 \\ 1 学生会員 名古屋大学大学院 工学研究科土木工学専攻（†464-8603 名古屋市千種区不老町） \\ E-mail:mori.hirotaka@j.mbox.nagoya-u.ac.jp \\ 2 正会員 名古屋大学大学院准教授 工学研究科土木工学専攻（†464-8603 名古屋市千種区不老町） \\ E-mail:hirohata@civil.nagoya-u.ac.jp
}

\begin{abstract}
既設鋼構造物の補修に溶接接合を適用する場合, 溶接残留応力が疲労強度に及ぼす影響や入熱による熱 影響部の脆化が懸念される.これに対し溶接後熱処理の適用を考えると, 薄い鋼板で構成されることの多 い土木鋼構造物では熱処理に伴う入熱による変形が生じる可能性がある. 本研究では, 薄い鋼板で構成さ れる部材の溶接後熱処理過程における応力緩和および変形挙動の解明を目的に，鋼板にビードオンプレー 卜溶接を施し局所加熱による溶接後熱処理を行った。また，熱弾塑性解析による実験のシミュレーション を実施した。一連の実験および解析の結果から，鋼板全体の残留応力分布を低減させ，熱処理中の面外変 形を抑制する熱処理条件を提案した.
\end{abstract}

Key Words: welding residual stress, post-weld heat treatment, stress release annealing, out-of-plane deformation

\section{1. 緒言}

橋梁に代表されるインフラ構造物の経年劣化に伴う損 傷が多数報告されており，既設のインフラ構造物を適切 に補修補強し維持管理していくことが社会的に重要な課 題となってきている ${ }^{1)}$. 鋼橋においても腐食や疲労によ る損傷事例が増えており, 補修補強, 維持管理の必要性 が高まってきている ${ }^{2}$ ， 現在，既設鋼橋の腐食減厚や疲 労き裂に対する補修部材の接合には，高力ボルトが広く 用いられている ${ }^{3)}$. 高力ボルト接合は品質の確保が容易 という利点がある一方で, 添接板やボルト分の重量増加 があることや，ボルト孔を設ける作業が必要なこと，狭 险で複雑な構造の桁端部などでは作業性に劣るという久 点がある.これに対し，異なる接合方法の選択肢として 溶接の可能性が考えられる. 溶接接合では，ボルト接合 に比べ重量増加が少なく，穿孔作業が不要であり，景観 上有利になるなど種々の利点が期待できる.

ただし，溶接を用いた補修では溶接残留応力が疲労強 度に及ぼす影響や入熱による熱影響部の脆化が懸念され る. 溶接残留応力は溶接金属の凝固冷却過程で内部応力 として生じ，溶接部近傍で引張となるため，疲労き裂の 発生，進展に影響を及ぼす。さらに，既設構造物では周 辺部材の拘束が影響し，より高い引張応力が生じる可能 性がある. また，引張応力につり合うように生じる圧縮
残留応力は，部材の耐荷力に影響を及ぼす，一方で，鋼 は $\mathrm{A}_{1}$ 変態点 (約 $720^{\circ} \mathrm{C}$ ) を超えて加熱され, 急冷される 過程で金属組織が粗大化し，硬く脆い組織へと変化する. 溶接による入熱と冷却過程で鋼が硬化し延性が低下する ことは, 部材の力学性能を低下させる一要因となる.

この種の問題に対し, 溶接後熱処理 (PWHT : Postweld Heat Treatment）の適用の有効性が一般に知られてい る. 溶接後熱処理とは，溶接部を所定の温度（炭素鋼で 約 $\left.600^{\circ} \mathrm{C}\right)$ に加熱・保持し, 徐冷する熱処理である ${ }^{4}$. 熱処理の過程で溶接残留応力を除去し，粗大化した熱影 響部の金属組織を微細化することが可能であり，溶接補 修部の品質を確保することが可能となる.

溶接後熱処理は一般に圧力容器やパイプラインなどの 溶接部に適用されている技術であるが 5)，鋼橋に代表さ れる土木鋼構造物では適用例が少ない，その理由として， 一般に溶接後熱処理では対象となる構造物全体を加熱炉 に入れて熱処理を行うが，大型の土木鋼構造物を収容で きる大規模な加熱炉が必要となる.また，補修溶接部に 対し溶接後熱処理を行う際, 現場で加熱炉を使用するこ とは現実的に不可能と言える. 加えて, 圧力容器などの 構造物と比較して土木鋼構造物は板厚が薄く, 熱処理に よる変形が生じやすい可能性がある.これらの問題に対 し, 本研究では, 複雑な形状に対しても局所的な加熱が 可能な熱源としてセラミックヒーター（図-1）の適用を 
検討する. セラミックヒーターは火気不使用, 熱処理に 必要な高精度な温度管理，小型の発電機で使用可能など の点で現場での作業に適する. 圧力容器などの鋼構造物 では，溶接部の補修において，セラミックヒーターの溶 接後熱処理への適用性は既に実証されている 9 。著者ら は既往の研究において，このセラミックヒーターを用い て，すみ肉まわし溶接継手 》およびあて板溶接 ${ }^{8}$ に対し て溶接後熱処理を実施し, 溶接残留応力緩和効果を明ら かにした. 本研究では, 主に薄い鋼板で構成される土木 鋼構造物の溶接後熱処理過程における応力緩和挙動に加 えて，これまで検討していなかった変形生成挙動の解明 を目的とした一連の基礎的実験および数值解析を行う.

\section{2. 溶接実験および熱弾塑性解析}

\section{(1) 実験供試体}

実験供試体には事前に応力除去焼鈍した $500 \times 500 \times 12$ $\mathrm{mm}$ の SM400A 鋼板（図-2 (a)）9体（No. 1〜9）を用いた。 3 体は溶接を施さない鋼板供試体（No. 1 3）とし，残 りの 6 体の鋼板には中央線に沿って $\mathrm{CO}_{2}$ 半自動溶接によ りビードオンプレート溶接を施し（図-2 (b)），溶接供 試体（No. 4 9）とした. 溶接供試体のうちの 3 体（No. 4〜6）に対し応力弛緩法により残留応力を測定した. 溶 接ワイヤには JIS YGW12（直径 $1.2 \mathrm{~mm}$, 軟鋼・490 $\mathrm{N} / \mathrm{mm}^{2}$ 級高張力鋼 ${ }^{9)}$ ) を用いて, 電圧 $20 \mathrm{~V}$, 電流 $150 \mathrm{~A}$ の条件で行った．溶接速度は平均 $5.5 \mathrm{~mm} / \mathrm{s}$ であった. 鋼 板および容着金属の化学成分と機械的性質（鋼板はミル シート值，溶着金属はカタログ值）を表-1 に示す。

\section{（2）溶接過程の熱弾塑性解析}

溶接実験の熱弾塑性解析には ABAQUS Ver. 6.13 使用 した。解析モデルを図-3に示す．対称条件より供試体 の $1 / 2$ をモデル化した. 要素には 8 節点ソリッド低減積 分要素を用いて, 温度-変位連成解析を行った。 また, 解析では幾何学的非線形性を考慮している.

力学的境界条件としては図-3 (b)に示寸ように, 解析 モデルの対称面における $\mathrm{y}$ 軸方向の変位を固定し, 底面 の 2 点 $(\mathrm{x}=0 \mathrm{~mm}, \mathrm{y}=0 \mathrm{~mm}, \mathrm{z}=0 \mathrm{~mm}$ および $\mathrm{x}=500 \mathrm{~mm}$, $\mathrm{y}=0 \mathrm{~mm}, \mathrm{z}=0 \mathrm{~mm})$ においてそれぞれ $\mathrm{x}$ 軸方向および $\mathrm{z}$ 軸方向の変位と, $\mathrm{z}$ 軸方向の変位を固定することで解析 モデルの剛体変位を拘束した. 熱的境界条件としては供 試体の表面から空気中への熱伝達を考慮した．材料の機 械的性質および物理定数については実験に基づく既往の

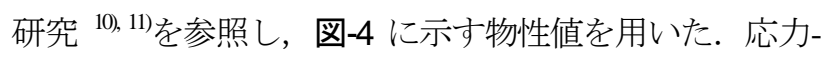
ひずみ関係はトリリニア型とし，等方硬化則を用いた。 熱影響部は母材と同じ物性值を用いた。

溶融部の形状は断面マクロ写真より決定し（図-3 (a)）, 各試験体の平均的な值として, 溶込み深さ 1.5 $\mathrm{mm}$, 余盛高さ $2.5 \mathrm{~mm}$, ビード幅 $7.5 \mathrm{~mm}$ (半幅 $3.75 \mathrm{~mm}$ ) とした. 溶融部に物体熱流束による入熱を投与するとと もに, 溶接部の剛性の変化を再現するため, 要素生成機 能により溶着金属を順次供給した．溶接部に投与寸る入 熱量は式(1)に基づき溶接条件から決定した。ただし， 溶接速度には溶接供試体 6 体の平均值 $(5.5 \mathrm{~mm} / \mathrm{s})$ を用 いた．アーク溶接の熱効率 $\eta$ は $0.65 〜 0.8$ であることが 知られている ${ }^{12}$. 熱効率 $\eta$ を種々変化させて試行的に解 析を行い，実験の温度履歴を再現できる $\eta=0.7$ を熱効率 $\eta$ として採用した.

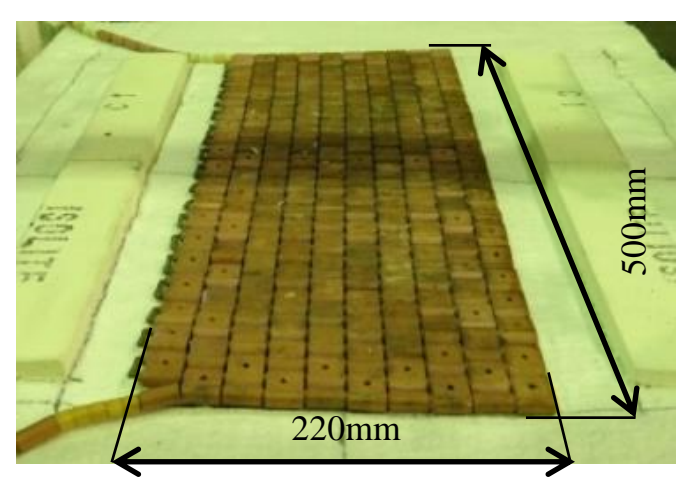

図-1 セラミックヒーター

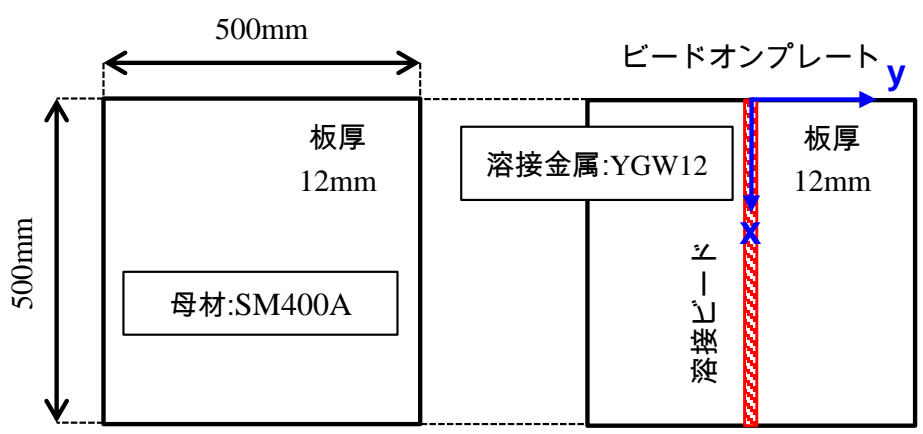

(a) 鋼板供試体 (b) 溶接供試体

図-2 実験供試体

表-1 供試鋼材の化学組成と機械的性質（ミルシート值およびカタログ值）

\begin{tabular}{|c|c|c|c|c|c|c|c|c|}
\hline & \multicolumn{5}{|c|}{ 化学成分 (\%) } & \multicolumn{3}{|c|}{ 機械的性質 } \\
\cline { 2 - 9 } & $\mathrm{C}$ & $\mathrm{Si}$ & $\mathrm{Mn}$ & $\mathrm{P}$ & $\mathrm{S}$ & $\begin{array}{c}\text { 耐力 } \\
\mathrm{MPa}\end{array}$ & $\begin{array}{c}\text { 引張強さ } \\
\mathrm{MPa}\end{array}$ & $\begin{array}{c}\text { 伸び } \\
\%\end{array}$ \\
\hline 鋼板 & 0.16 & 0.14 & 0.71 & 0.012 & 0.004 & 306 & 442 & 32 \\
\hline 溶着金属 & 0.09 & 0.44 & 0.96 & 0.012 & 0.012 & 460 & 540 & 28 \\
\hline
\end{tabular}




$$
Q=\eta E I / v
$$

$$
\begin{gathered}
\text { ここに, } Q: \text { 入熱量 }(\mathrm{J} / \mathrm{mm}) \\
\eta: \text { 熱効率 } \\
E: \text { 溶接電圧 }(\mathrm{V}) \\
I: \text { 溶接電流 }(\mathrm{A}) \\
v: \text { 溶接速度 }(\mathrm{mm} / \mathrm{s})
\end{gathered}
$$

\section{（3）実験結果と解析結果の比較}

溶接時の温度履歴，溶接変形，溶接残留応力の実験結 果と解析結果の比較を図-5 に示す．解析では，実験時 の室温 $\left(30^{\circ} \mathrm{C}\right)$ と供試体の温度が同等になるまで十分な 冷却時間（20 時間程度）を設けているが，図には温度 変化が小さくなる 500 秒までの履歴を示している. シン ボルが実験值，実線が解析值を示しており，比較は寸心゙
て溶接線方向の中央の位置 $(\mathrm{x}=250 \mathrm{~mm}$, 図-3 (b)の青い 破線上）で行った．図-5 (a)は溶接ビードの中心部から それぞれ $15 \mathrm{~mm}, 30 \mathrm{~mm}, 45 \mathrm{~mm}$ 離れた位置での上表面 の温度履歴である. 実験值には 6 体の溶接速度が平均值 と最も近い No. 5 の結果を用いた. 図-5 (b)の溶接変形の 実験值には溶接供試体 6 体の平均值を用いて比較し，図 -5 (c)は溶接供試体のうち, 残留応力測定用の 3 体の平均 值を用いた. 残留応力の測定には応力弛緩法 ${ }^{8)}$ を用いた が，供試体の溶接ビード側の表面に 2 軸ひずみゲージを 貼付してひずみゲージの周辺を切断し，解放されるひず みを計測し残留応力を推定した．切断された小片は，一 辺が $10 \mathrm{~mm}$ 程度となるように切断した（図-6）。ただし, 応力弛緩法では上表面に貼付したひずみゲージから推定 される残留応力が，上表面の応力ではなく板厚方向の平 均的な值に近くなる可能性がある，そこで，解析におい

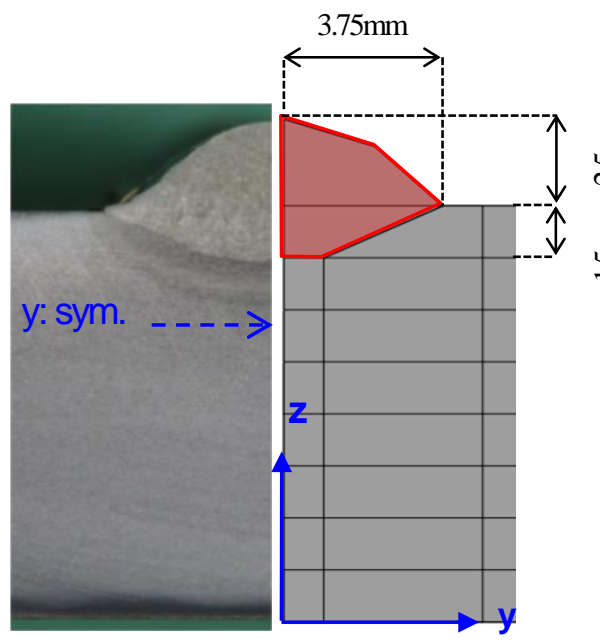

(a) 溶融部の断面マクロ写真とメッシュ形状

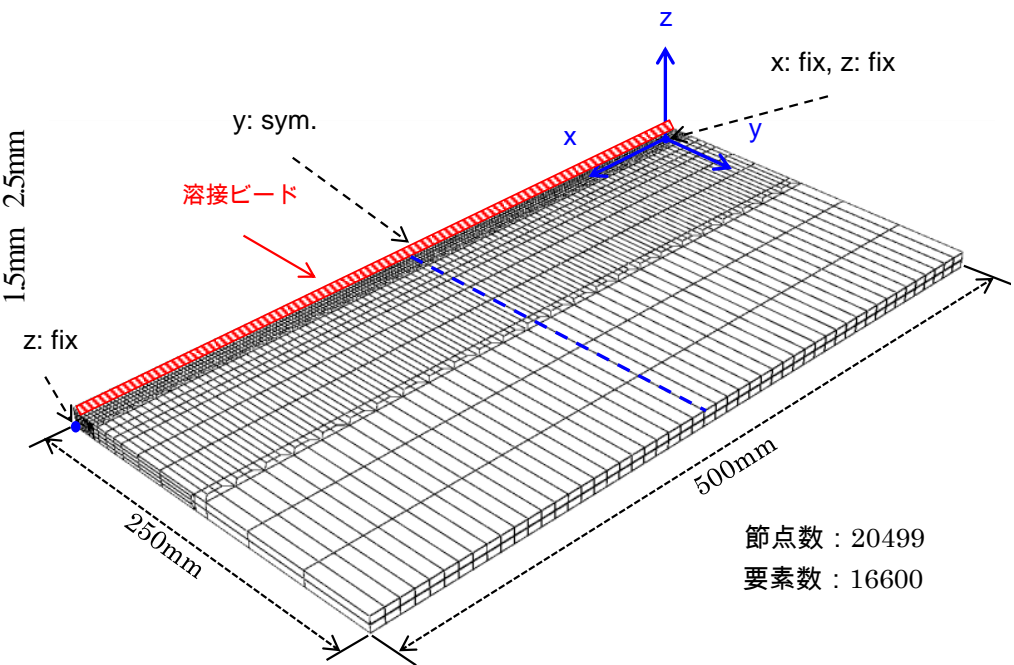

(b) メッシュ形状および境界条件

図-3 溶接供試体の解析モデル

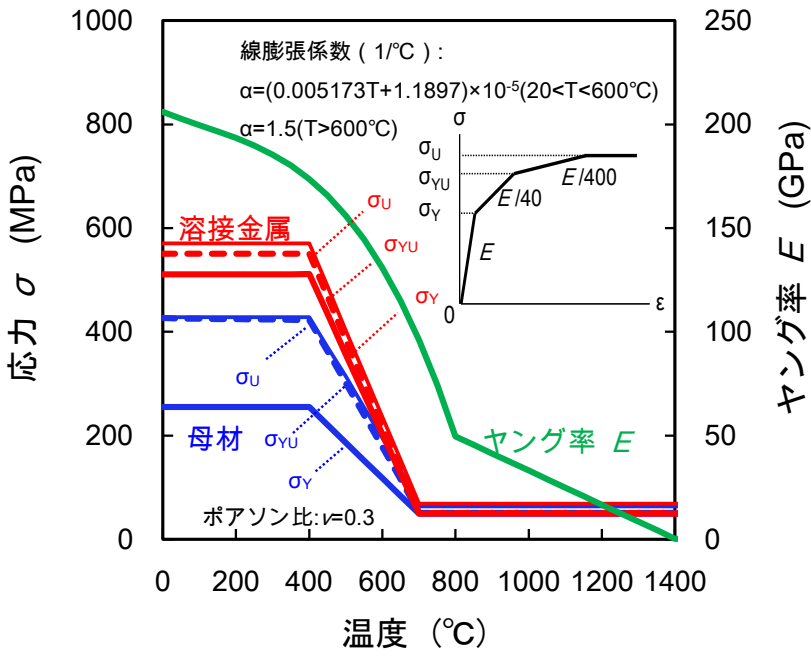

(a) 機械的性質

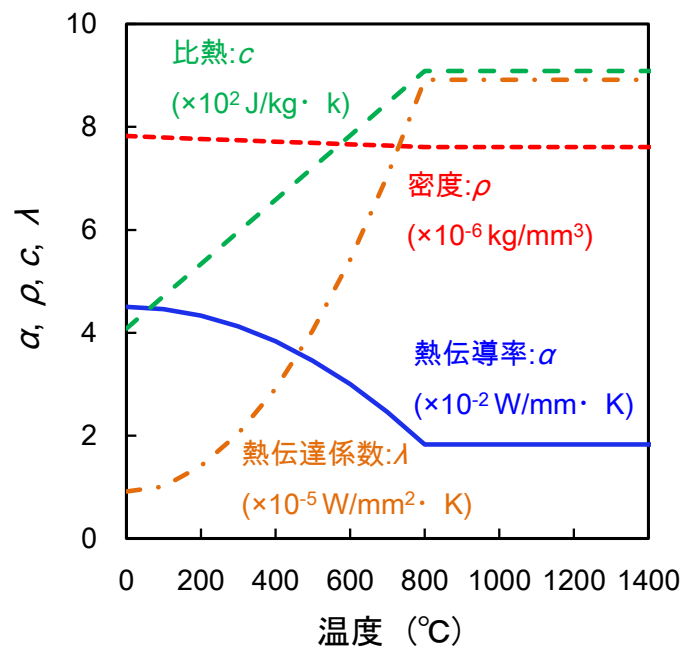

(b) 物理定数

図-4 材料の機械的性質および物理定数 
て表面の残留応力だけでなく板厚方向の残留応力の平均 值も求め，実験值と比較した。溶接ビード近傍において のみ有意な差が確認でき，特に $\sigma_{x}$ において表面より平 均值の方が実験值に近くなることが分かった。一連の実 験結果と解析結果を比較すると，両者は概ね一致してお り，熱弾塑性解析により溶接実験を精度よく再現するこ とができた。

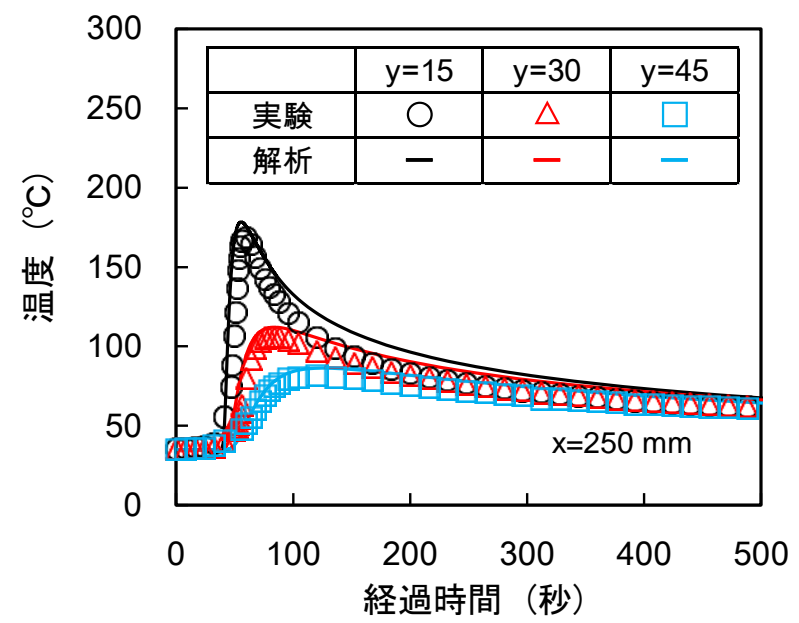

(a) 溶接時の温度履歴

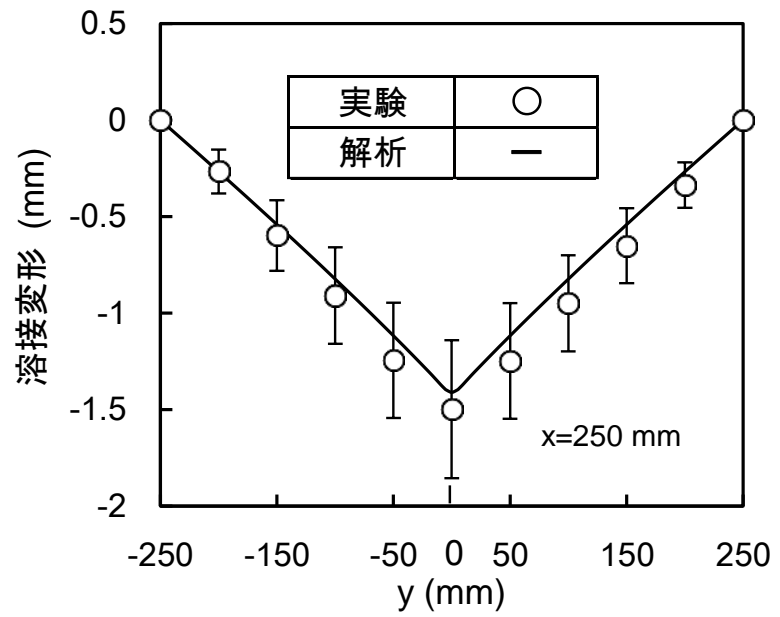

(b) 溶接変形

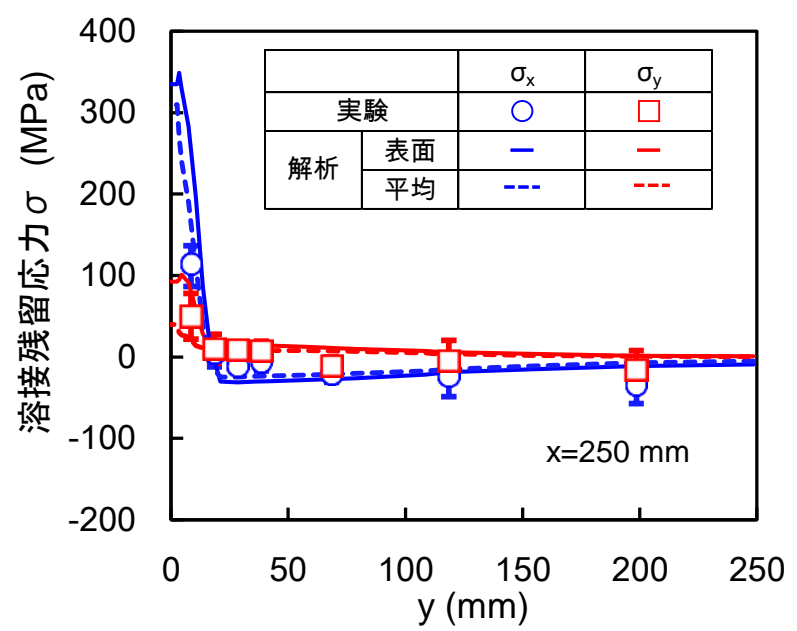

(c) 溶接残留応力

図-5 溶接実験の結果および解析結果

\section{3. 溶接後熱処理実験および熱弾塑性解析}

\section{（1） 実験方法}

a) 溶接後熱処理条件

溶接供試体のうち熱処理用の 3 体（No. 7 9） と，鋼 板供試体 3 体に溶接後熱処理を実施した．溶接後熱処理 時の入熱にはセラミックヒーター（図-1）を使用し，JIS $\mathrm{Z} 3700^{13)}$ に規定される加熱条件を満たすように鋼板に熱 電対を取り付けて温度管理を行った．表-2 に JIS Z 3700 に定められた $425{ }^{\circ} \mathrm{C}$ 以上における温度制限と実験条件の 比較を示す．熱処理時には，図-7 の(1)〜6)の位置に熱 電対を取り付け，(1)熱電対の温度をモニターしながら 所定の温度履歴を満たすように，ヒーターの入熱を自動 制御するプログラムを設定した.

JIS Z 3700 の規定に従い溶接ビードの左右に有効加熱 幅（板厚の 2 倍）を加えた範囲（図-8）を含むように加 熱し，有効加熱幅内で最低保持温度である $595^{\circ} \mathrm{C}$ を満た し，被加熱部全体で温度差が $85{ }^{\circ} \mathrm{C}$ 以下となるように温 度管理を行った．熱処理時には供試体を厚さ $75 \mathrm{~mm} の$ 断熱材で覆った. 熱処理終了後, 応力弛緩法により残留 応力を測定した.

\section{b) 面外変形計測方法}

溶接後熱処理時には鋼板の 3 点（鋼板の縁 2 点と中央 1 点）で鉛直変位を測定し，縁に対する中央の相対鉛直 変位を求めた（図-9 (a)）。溶接供試体には溶接後熱処 理開始時点で，V 字形の溶接変形が生じていた。溶接変 形の向きと加熱面の関係について検討するため，供試体 の下側にヒーターを設置して片面から加熱を行い，2 体

（No. 7，8）は溶接ビード側を下向きに，1 体（No. 9） は溶接ビード側を上向きにして加熱した。

鉛直変位は供試体の上方に組んだフレームに変位計 を固定し，変位計が高温になり測定誤差が生じることを 防ぐために，供試体の上に設置した耐熱ブロックに変位 計の針を当て測定した（図-9 (b)，(c)）。熱処理過程に おける変位計先端の温度は保証值である $70{ }^{\circ} \mathrm{C}$ 以下にな っていることを確認した。

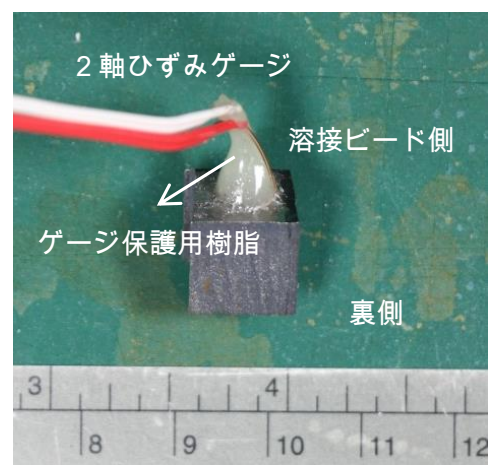

図-6 残留応力測定用の切断小片 


\section{（2）熱影響部の硬さおよび金属組織}

熱処理の効果を治金的観点から検証することを目的と して，硬さ試験および金属組織観察を行った．図-10に ビッカース硬さ試験結果を示す．溶接部断面の縁から $10 \mathrm{~mm} （ \mathrm{z}=10 \mathrm{~mm} ）$ の熱影響部において, 溶接後に 250 $\mathrm{Hv}$ 程度であった熱影響部の硬さは, 熱処理後に $200 \mathrm{Hv}$ 程度まで低下した．熱処理の前後で母材および溶接金属 のビッカース硬さに変化はなかった.

また，溶接後熱処理の前後での金属組織の変状を確認
するために組織観察を行った．金属組織写真を表-3に 示寸. 溶接後熱処理時の最高加熱温度 (約 $\left.600{ }^{\circ} \mathrm{C}\right)$ が $\mathrm{A}_{1}$ 変態点である約 $720^{\circ} \mathrm{C}$ 以下であったため，母材部では 金属組織にほとんど変化が見られなかった。一方，熱影 響部および溶接金属では，溶接後に確認できた粗大な結 晶構造が熱処理後に確認できなくなったことから，組織 が再結晶により微細化したと判断した. 治金的観点から 適切に溶接後熱処理が行われたことを結果は示唆してい る.

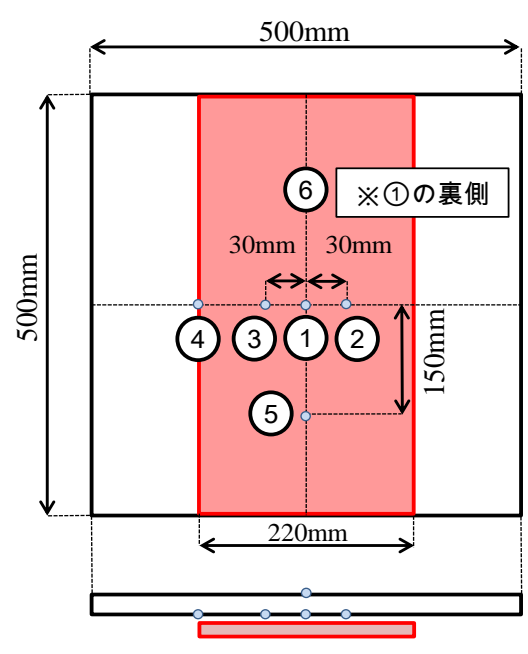

図-7 熱電対の取り付け位置

表-2 実験溶接後熱処理条件 ${ }^{13)}$

\begin{tabular}{|c|c|c|}
\hline & JIS Z 3700 & 実験条件 \\
\hline $\begin{array}{c}\text { 加熱速度 } \\
\left(425{ }^{\circ} \mathrm{C} \text { 以上 }\right)\end{array}$ & 最大 $220^{\circ} \mathrm{C} / \mathrm{h}$ & $150^{\circ} \mathrm{C} / \mathrm{h}$ \\
\hline $\begin{array}{c}\text { 冷却速度 } \\
\left(425^{\circ} \mathrm{C} \text { 以上 }\right.\end{array}$ & 最大 $280^{\circ} \mathrm{C} / \mathrm{h}$ & $150^{\circ} \mathrm{C} / \mathrm{h}$ \\
\hline 保持温度 & 最低 $595^{\circ} \mathrm{C}$ & $600^{\circ} \mathrm{C}$ \\
\hline 保持時間 & 最短 $\mathrm{t} / 25$ 時間 & 1 時間 \\
\hline
\end{tabular}

※ただし，tは溶接部の板厚 $(\mathrm{mm})$

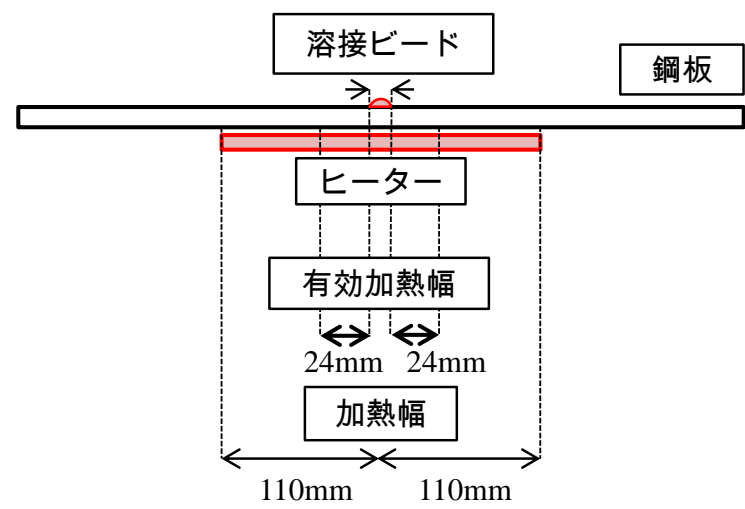

図-8 加熱範囲

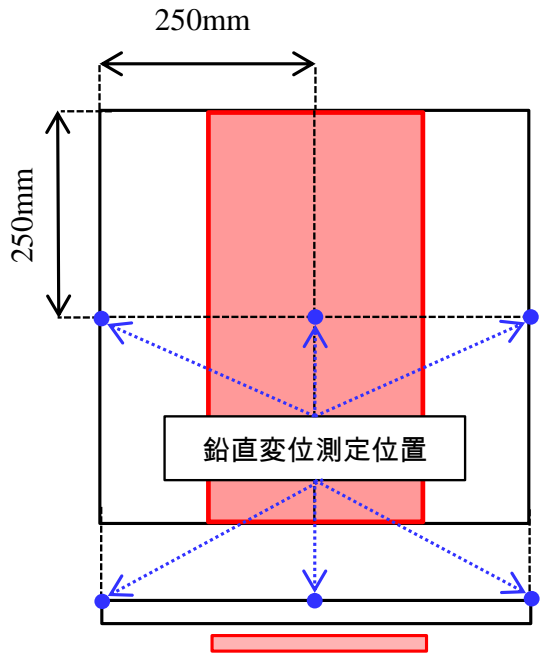

(a) 鉛直変位の測定位置

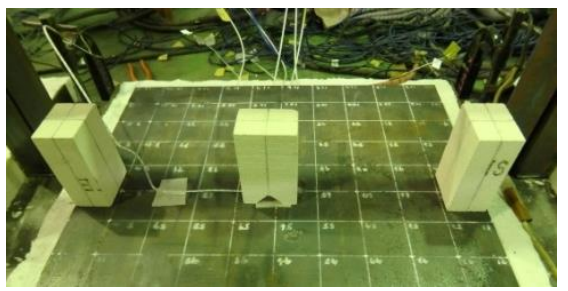

(b) 供試体上の耐熱ブロック

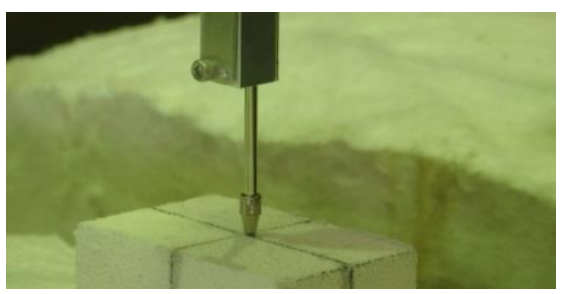

(c) 而埶ブロック上の変位計の針

図-9 変位計測の状況 
表-3 熱処理前後の金属組織写真

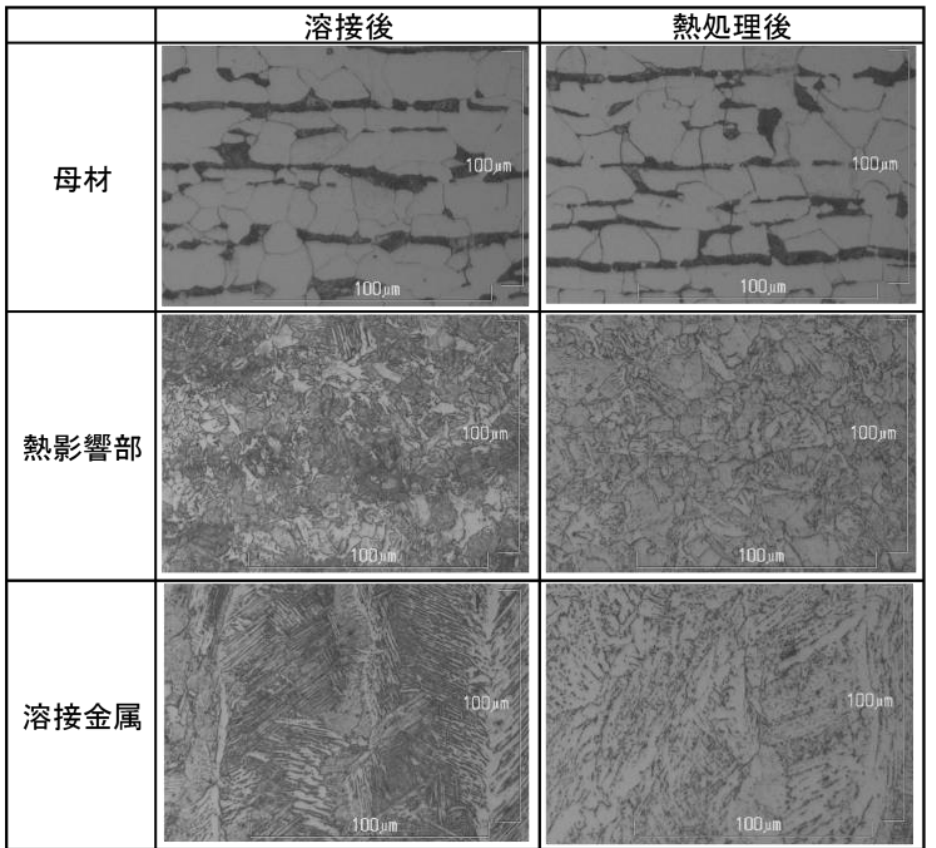

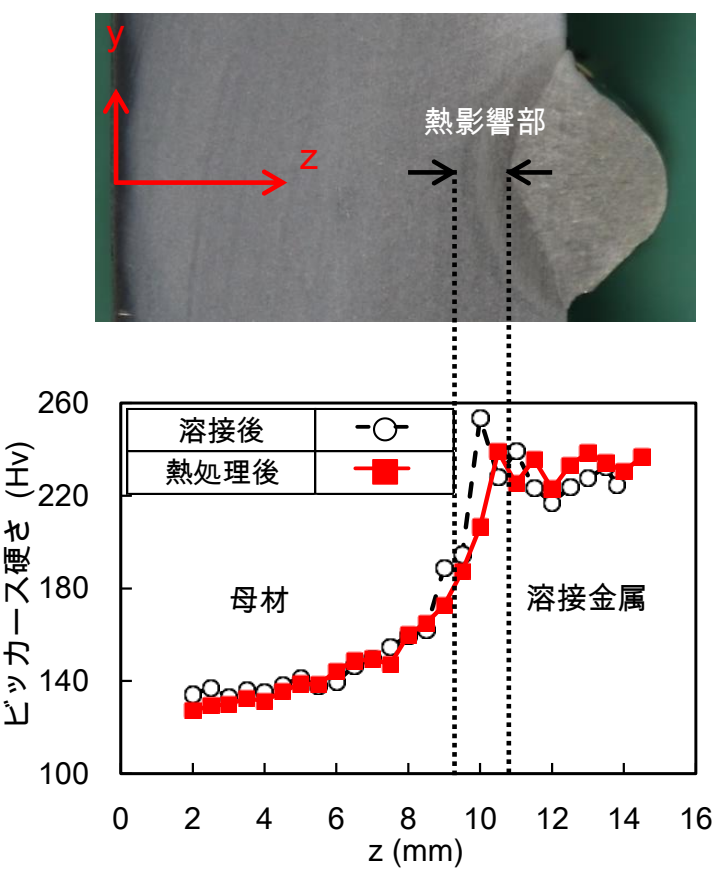

図-10 ビッカース硬さ試験結果

\section{（3）溶接後熱処理過程の熱弾塑性解析}

溶接後熱処理過程の熱弾塑性解析には，溶接過程の熱 弾塑性解析に用いたモデルに溶接後熱処理の過程を追加 したモデルを作成し使用した．解析条件は溶接過程のモ デルを踏襲し，クリープひずみと断熱材の存在を考慮し た熱伝達係数 7, 14)を新たに導入して解析を行った．セラ ミックヒーターからの入熱は表面熱流束により加熱面か ら投与したが，セラミックヒーターの入熱量を決定する 一般的な方法がないため，入熱面においては解析の時間 ステップごとに入熱量を逐次変化させ，実験時の温度履 歴を再現した ${ }^{14}$ 。 溶接ビード側，溶接ビードの裏側それ ぞれで入熱面を変えて，加熱面の違いを再現した．クリ ープひずみには文献 ${ }^{15)}$ 参照し，式(2)で表されるクリー プ則を使用した。このクリープ則は，応力緩和機構を表 現するのに適するとされる時間硬化則による定常クリー プを考慮したものである ${ }^{16}$ ．なお，クリープひずみは $400^{\circ} \mathrm{C}$ 以上で発生するものとした.

$$
\begin{aligned}
\varepsilon_{c r}(t, T, \sigma) & =\frac{1}{100} a(T)\left(\frac{t}{60}\right)^{b(T)}\left(70.5 \frac{\sigma}{\sigma_{u R T}}\right)^{c(T)} \\
a(T) & =\left\{\begin{array}{lr}
10^{-(13.25-0.00851 \times 20)} & (T<20) \\
10^{-(13.25-0.00851 T)} & (20 \leq T<725)
\end{array}\right. \\
b(T) & =-1.1+0.0035 T \\
c(T) & =2.1+0.0064 T
\end{aligned}
$$

ここに, $\sigma$ : 応力 $(\mathrm{MPa})$

$\sigma_{u R T}$ :引張強度 (MPa)

$T$ : 温度 $\left({ }^{\circ} \mathrm{C}\right)$

$t \quad:$ 時間 $(\mathrm{s})$
ベき乗数

$$
: \frac{1}{100} a(T)\left(\frac{1}{60}\right)^{b(T)}\left(\frac{70.5}{\sigma_{u R T}}\right)^{c(T)} b(T)
$$

相当応力次数 $: c(T)$

時間次数 $\quad: b(T)-1$

断熱材を考慮した熱伝達係数を図-11 (a)に示す. 熱電 対を取り付けた鋼板を電気炉で加熱し，溶接後熱処理で 用いたものと同じ厚さ $75 \mathrm{~mm}$ の断熱材で被覆した鋼板 の冷却過程における温度履歴（図-11 (b)）を記録した. 解析において熱伝達係数を種々変化させ，その温度履歴 を再現することで逆算的に推定した.

\section{(4) 実験結果と解析結果の比較}

\section{a) 溶接後熱処理時の温度履歴}

溶接後熱処理時の温度履歴の実験值と解析值の比較を 図-12 に示寸．図-12 (a)より，有効加熱幅の範囲では最 低保持温度である $595{ }^{\circ} \mathrm{C}$ 上回っていることが確認でき, 解析において実験時の温度履歴を再現できたと判断した。 図-12 (b)より，実験時には被加熱部全体で温度差を $85{ }^{\circ} \mathrm{C}$ 以下に抑えられていたことが分かった。解析にお いてもこの温度履歴を再現することができた．また，図 -12 (c)より, 供試体の表裏では温度差はほとんど生じて いないことを確認した.

\section{b) 残留応力}

溶接後熱処理前後の残留応力分布を図-13 に示寸．シ ンボルは応力弛緩法により求めた実験值の平均值を示し ており，実線は溶接ビード側から加熱した解析結果を示 しているが，加熱面の違いによる残留応力の差はほとん ど見られなかった．溶接ビードに近い範囲においては, 


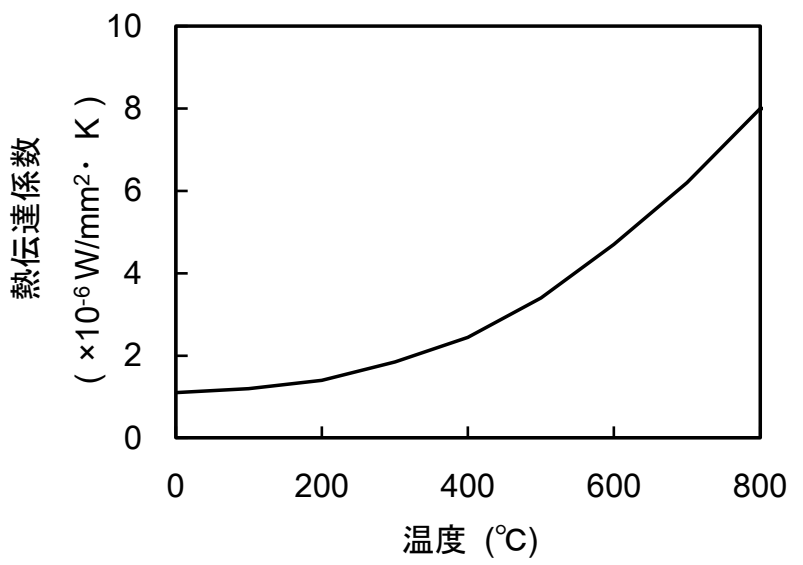

(a) 断熱材を考慮した熱伝達係数

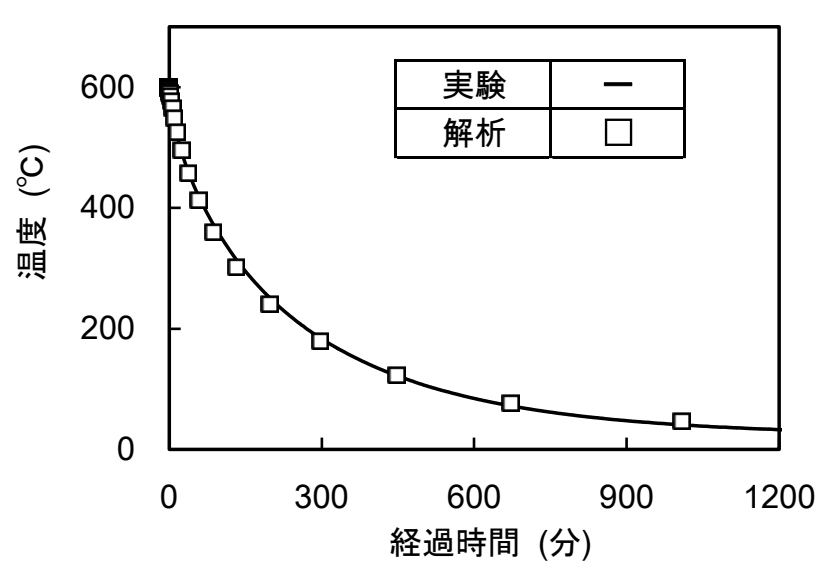

(b) 断熱材により被覆した鋼板の温度履歴

図-11 断熱材を考慮した熱伝達係数の推定

残留応力が低下したことが分かった，一方で，鋼板およ び溶接供試体の両者で，加熱範囲の外側においては溶接 後熱処理後に圧縮応力が増加する傾向があり, また, 加 熱範囲内の溶接ビード近傍以外では引張残留応力が増加 寸る傾向が確認された。 以上の結果から，局所加熱に よる溶接後熱処理過程により溶接ビード近傍においては 残留応力低減の効果が得られた可能性があるが，それ以 外では熱処理過程で残留応力が増加した可能性があると 判断した.

\section{c) 面外変形挙動}

溶接後熱処理時の鋼板供試体（No. 1）および溶接供 試体（No. 7，9）の面外変形挙動を図-14 に示寸. 3 体の 鋼板供試体の面外変形挙動の特徵は概ね同じ傾向であり, 2 体の溶接ビード側を下向きに設置し加熱した溶接供試 体も概小同じ傾向を示した．鋼板供試体，溶接供試体と もに熱処理後の面外変形を精度よく再現できた。一方， 溶接供試体の加熱および保持過程（約 300 分まで）の変 形挙動には差が見られる. 解析では一様に鋼板表面から 入熱したが，実験では溶接変形および容接ビードの存在 により，ヒーターと鋼板との間にわずかな隙間が生じて いたため，ヒーターと鋼板の接触が一様ではなく入熱が 不均一であった可能性がある.このような入熱の不均一 を解析で考慮しなかったことが，実験結果の再現精度に 影響を及ぼしたものと考えられる。これは，初期変形が 小さく溶接ビードのない鋼板供試体の面外変形挙動が精 度よく再現できていることからも推察される.

面外変形は主に加熱過程（約 200 分まで）において発 生していることが確認された. 溶接後熱処理後の鋼板供 試体には $0.03 \mathrm{~mm}$ 程度の残留変形が生じていた。一方, 溶接供試体では，溶接ビード側，溶接ビードの裏側いず れから加熱しても溶接による変形が大きくなる方向に変 形が増加し, $0.2 \mathrm{~mm}$ 程度の残留変形が生じた.

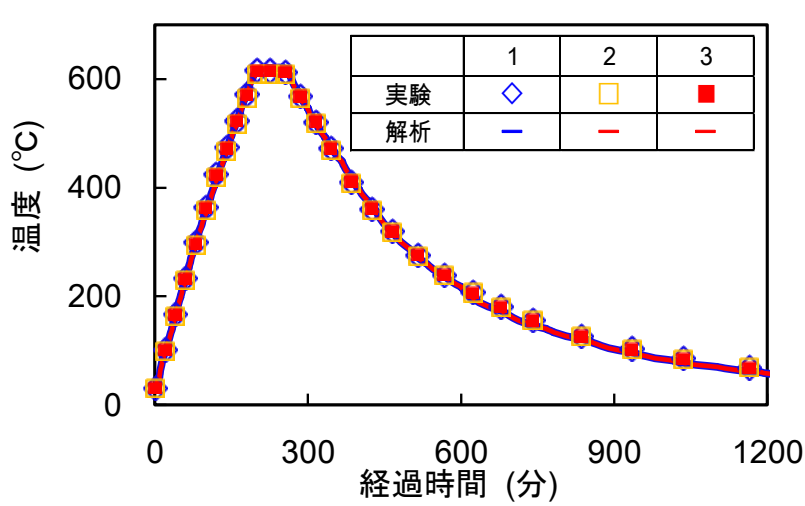

(a) 有効加熱幅内

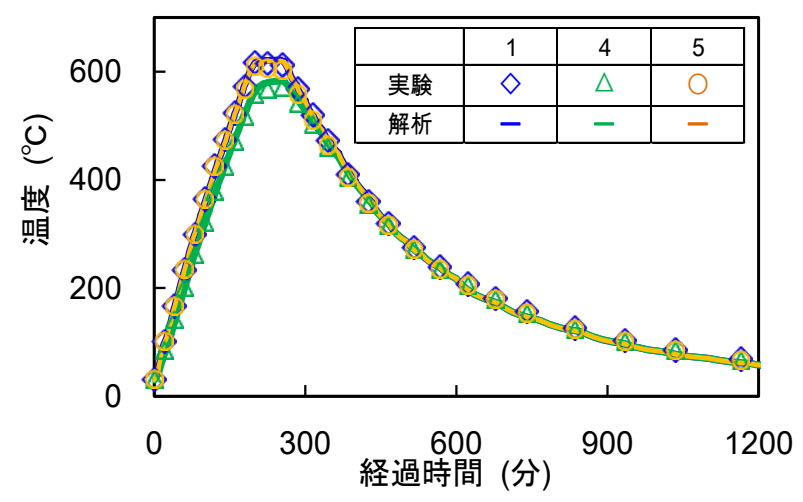

(b) 被加熱部全体

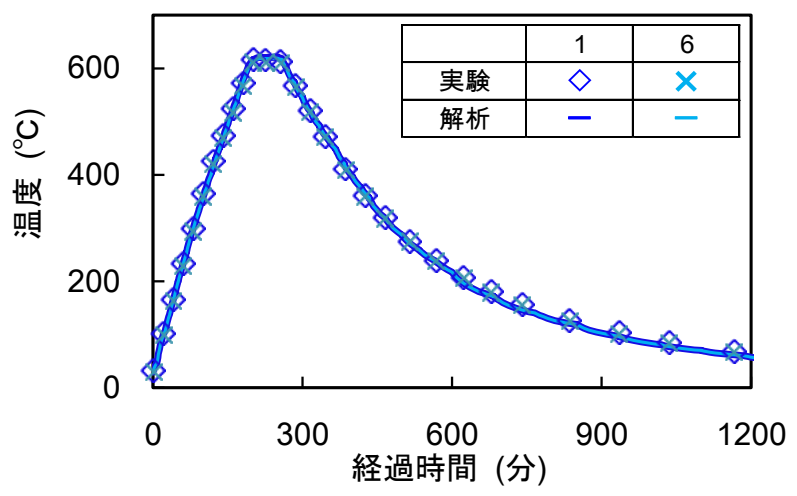

(c) 表裏

図-12 溶接後熱処理時の温度履歴 


\section{4. 考察}

\section{（1）熱処理過程における残留応力の挙動}

残留応力および面外変形の発生メカニズムを明らかに することを目的に，解析結果を基本とした一連の検討を 行う.

3. (4) b)において，JIS Z 3700 に規定される条件を満た 寸溶接後熱処理を行えば，溶接ビード近傍の引張残留応 力を緩和できることが分かった，ただし，溶接ビード近 傍以外に着目寸ると，溶接後熱処理による残留応力の低 減効果が不十分，もしくは熱処理により新たに応力が生 じる可能性が示された．そこで，溶接部近傍の局所領域 に限らず，鋼板全体の残留応力を抑制する加熱条件を解 析に基づいて検討する．そのため，まず，熱処理過程に おける残留応力の生成挙動を明らかにする.

解析モデルの中央線上における溶接ビード近傍の要素 の溶接後熱処理過程の応力変化挙動を図-15 に示す．保 持終了時点では応力がほぼゼロとなっているが，保持終 了後の冷却過程に入ると応力が増大していくことが確認 できた．これより，溶接後熱処理後の残留応力を低減す るためには，冷却時に発生する応力を抑制する必要があ ると分かる.

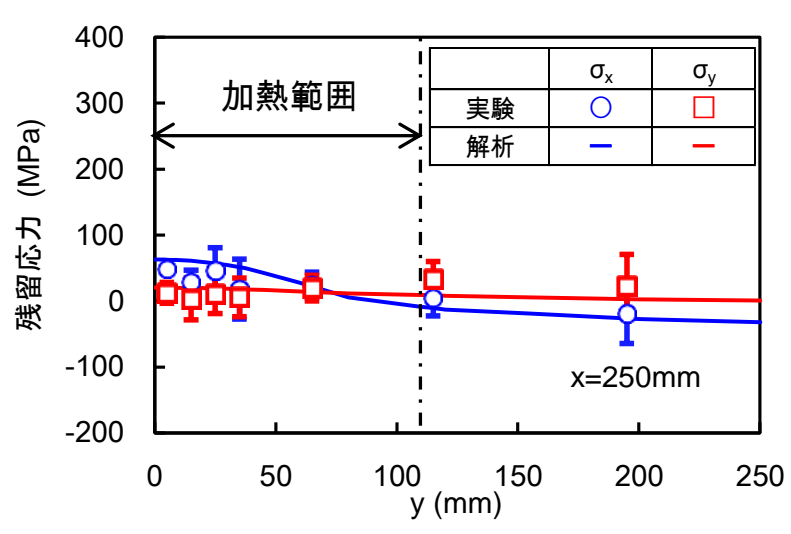

(a) 鋼板供試体

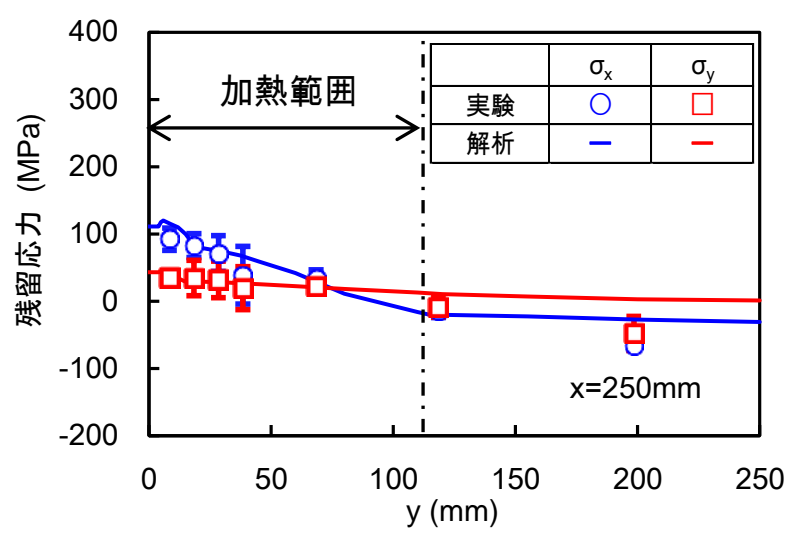

(b) 溶接供試体

図-13 溶接後熱処理の加熱条件による残留応力

\section{（2）残留応力低減効果のための加熱条件}

冷却時に応力が発生するメカニズムとしては，セラミ ックヒーターによる加熱を受ける領域と加熱されない領 域との間の温度差が考えられる. 鋼板内の温度差により 材料強度と岡性が位置によって異なることで，供試体内 の高温領域と低温領域で膨張，収縮の拘束が生じ，応力 が生成される. そこで，供試体内の温度差を小さくする ことにより応力を低減させる可能性を検証した．図-16 に，供試体の入熱幅（B とする）を $220 \mathrm{~mm}$ から $400 \mathrm{~mm}$ および $500 \mathrm{~mm}$ に拡大して解析した場合の残留応力を示

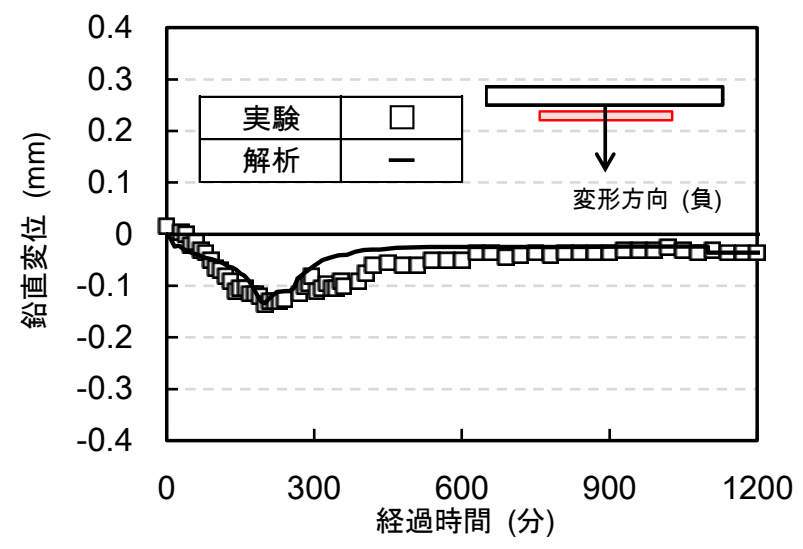

(a) 鋼板供試体

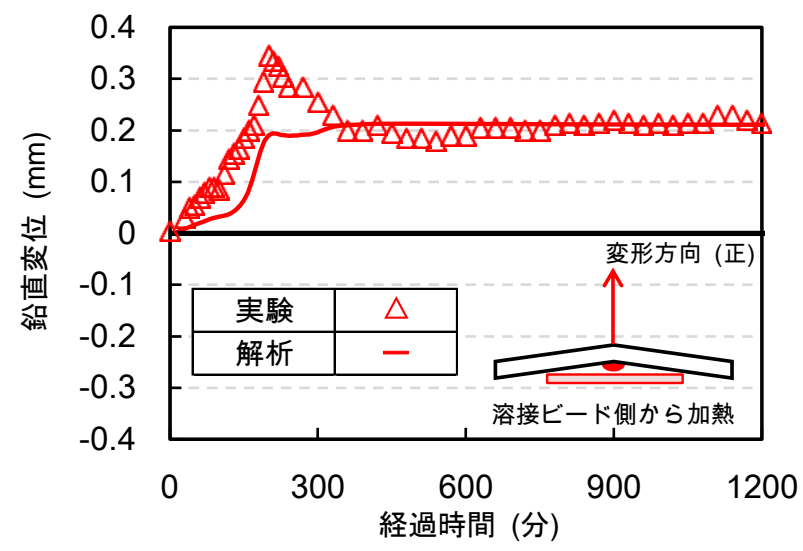

(b) 溶接供試体（溶接ビード側から加熱）

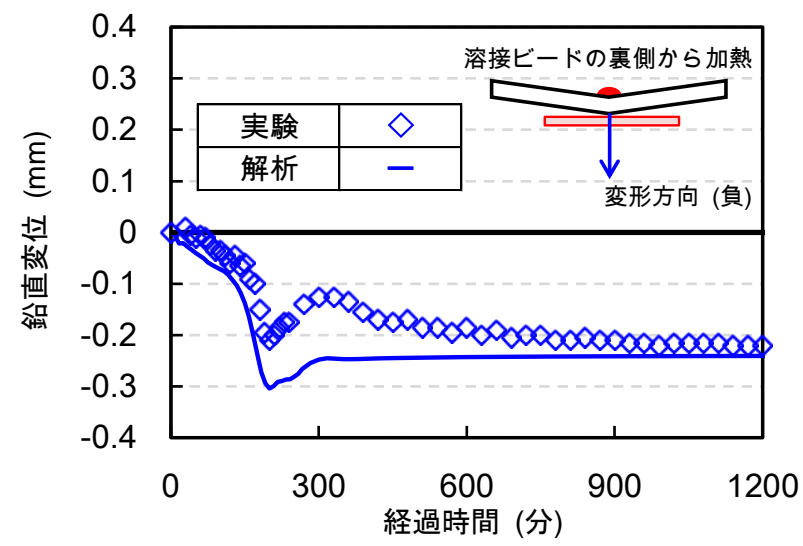

(c) 溶接供試体（溶接ビードの裏側から加熱）

図-14 溶接後熱処理の加熱条件による面外変形挙動 
す.ただし，入熱はすべて溶接ビード側から行った. 図 -16 (a)に $\mathrm{x}$ 方向, (b)に $\mathrm{y}$ 方向の残留応力成分の分布を示 す. 加熱, 保持および冷却過程の温度履歴は, 図-7の (1)の位置での温度履歴が実験と一致するように入熱量を 変化させた。

図-17に示すように，B=220 mmから B=400 mmおよび $\mathrm{B}=500 \mathrm{~mm}$ に拡大寸ると熱処理中の供試体の中心（ $\mathrm{y}=0$ $\mathrm{mm})$ と縁（y=250 mm）との加熱過程および冷却過程の 温度差は小さくなる.この温度差が小さくなるほど残留 応力が小さくなることが分かる（図-16）。以上の解析 結果から, 冷却過程の供試体内の温度差が最終的な残留 応力を決定寸る主要因であり, 鋼板全体の残留応力を抑 制するためには, 冷却過程における供試体内の温度差を 小さくすることの有効性が示唆された.

\section{（3）残留応力低減効果のための加熱条件}

4. (1)で示したように，冷却時に発生する残留応力を 抑制するためには，供試体の面内方向の温度差を小さく することが有効であると確認できた。ここで， B=220

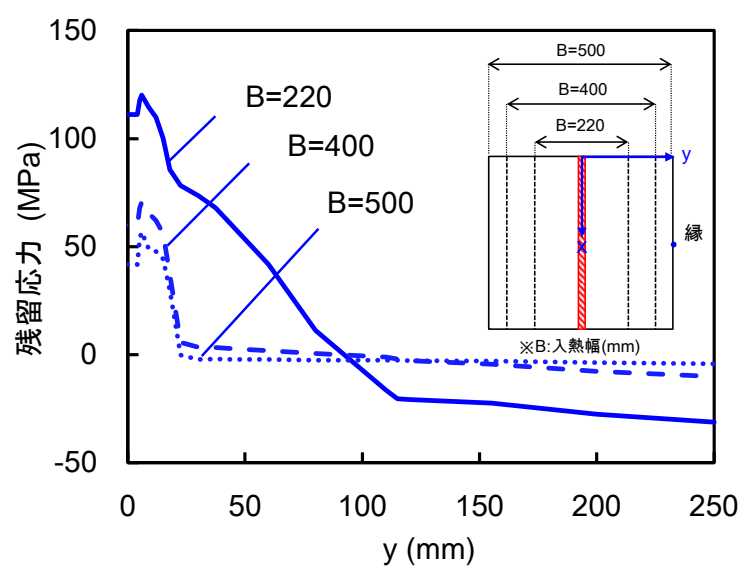

(a) 冷却後の $\sigma_{x}$ の比較 $\mathrm{mm}$ から $\mathrm{B}=400 \mathrm{~mm}$ および $\mathrm{B}=500 \mathrm{~mm}$ 一と拡大させた際 の, 面外変形挙動の比較を図-18 に示寸. 残留変形量を 比較すると， $0.21 \mathrm{~mm}$ から $0.11 \mathrm{~mm}$ および $0.08 \mathrm{~mm}$ までそ れぞれ低下したことが分かった. 入熱幅の拡大による面 内方向の温度差の抑制は, 残留応力のみならず面外変形 の低減にも効果的であることを結果は示唆している.

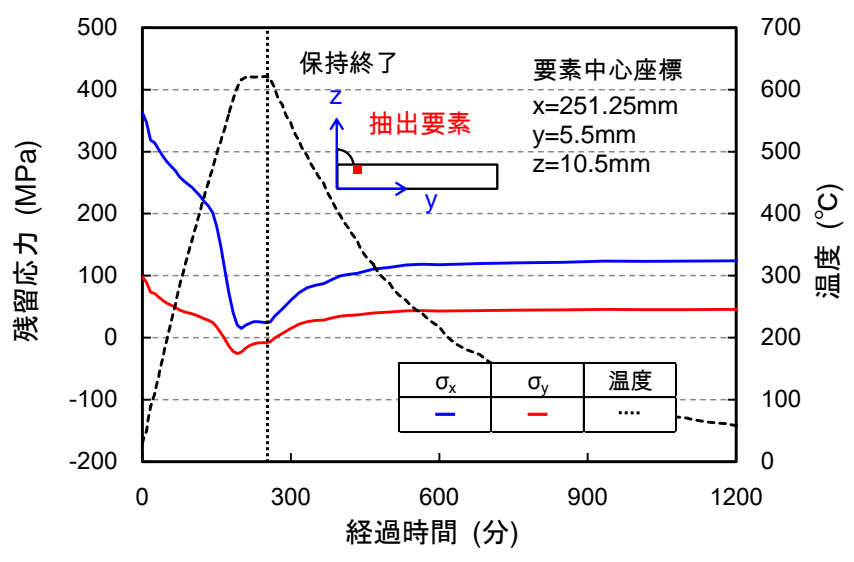

図-15 残留応力の変化履歴

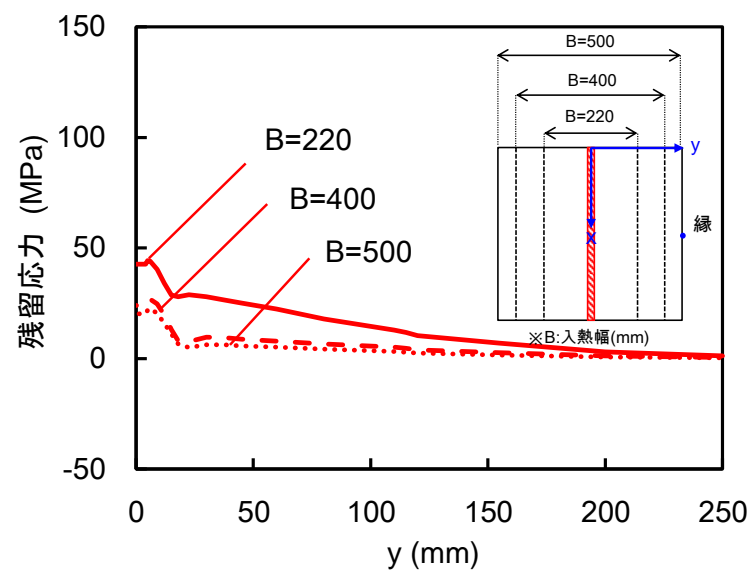

(b) 冷却後の $\sigma_{\mathrm{y}}$ の比較

図-16 入熱幅の違いによる冷却後の残留応力の比較

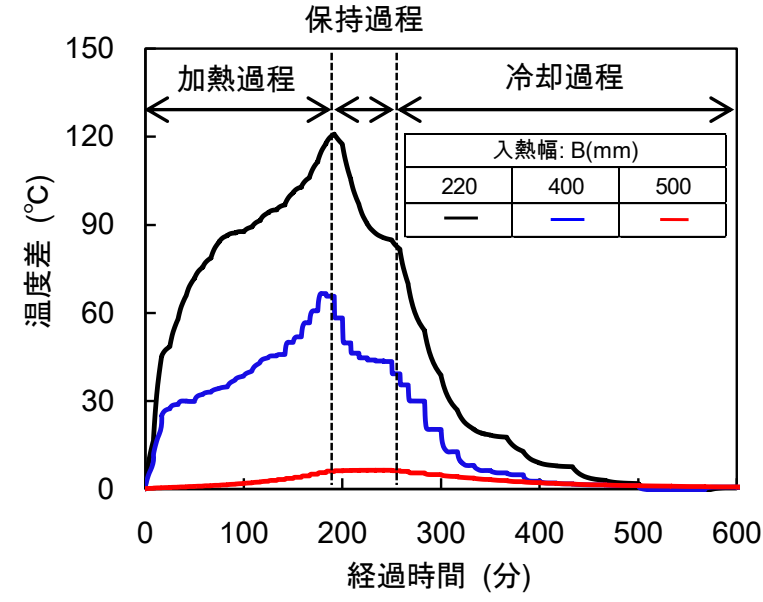

図-17 入熱幅の違いによる温度差の比較

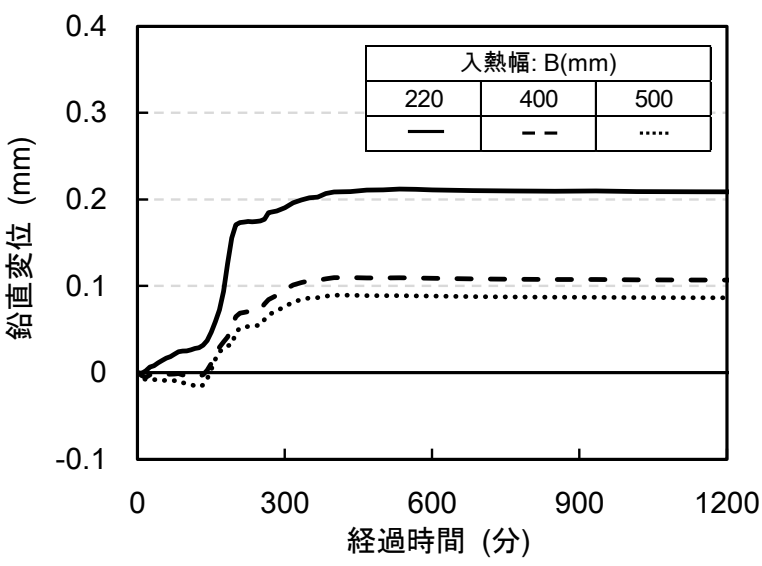

図-18 入熱幅の違いによる面外変形挙動の比較 


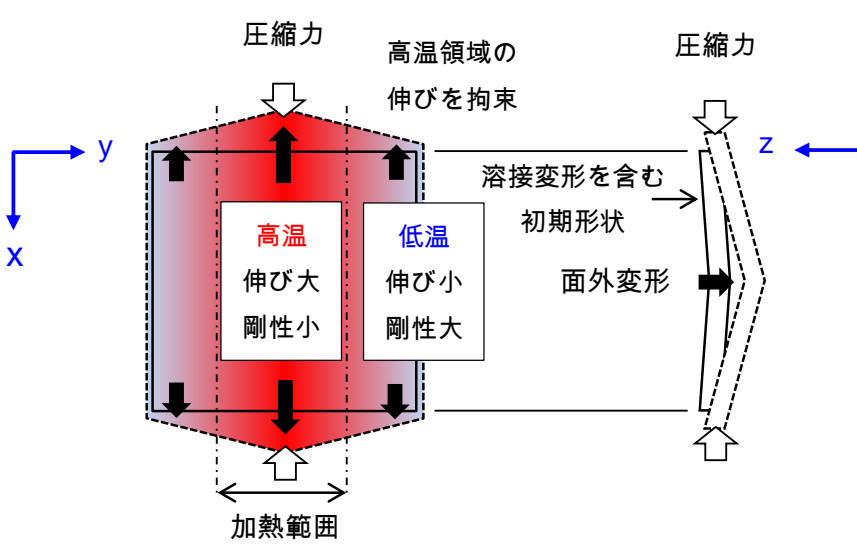

図-19 面外変形の発生メカニズム

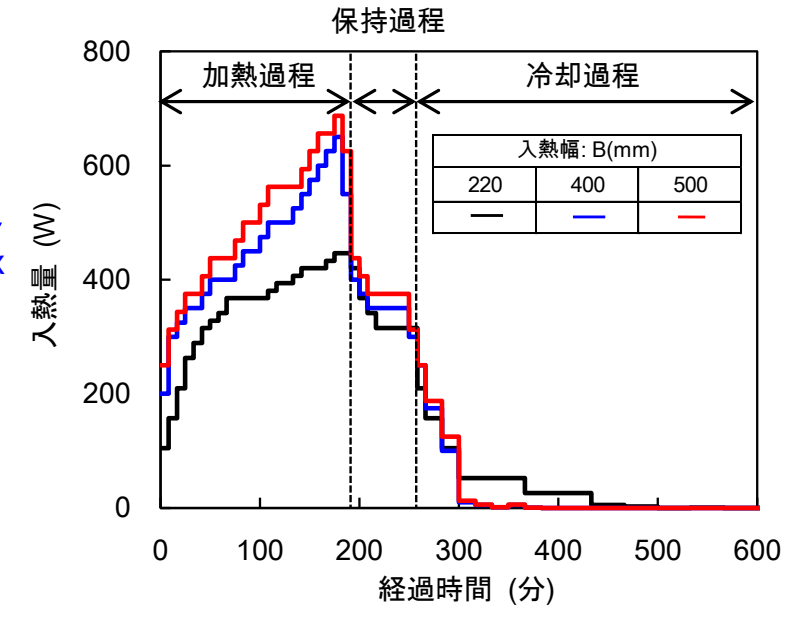

図-20 熱処理シミュレーションにおける入熱量
加熱過程における面内方向の温度差が面外変形の発生 原因であると考えられるが，そのメカニズムは次のよう に説明できる. 図-19 に示すように，局所的な加熱によ り供試体の面内方向に温度差が生じる. 4. (2)において 説明したように，材料強度および岡性は温度に依存して いるため, 高温部は剛性が低く大きく膨張する一方で, 低温部は剛性が高くあまり膨張しない，そのため，供試 体の面内方向で膨張量に差が生じ，高温部の伸びを低温 部が拘束することで高温部に圧縮力が作用する. この圧 縮力により, 溶接変形 (初期変形) が大きくなる方向一 と面外変形が生じたと推測できる.

入熱幅を拡大し供試体の面内方向の温度差を抑制する 手法は, 残留応力と面外変形の両者の低減に効果的であ ることが分かった．ただし，入熱幅すなわち入熱領域の 拡大は, 熱処理に要するコストの増加に関係する. 解析 において溶接後熱処理時の入熱量を比較した結果を図20 に示寸. 入熱幅が拡大寸ると入熱量も増加すること を確認した．また，最適な入熱領域は対象とする構造部 材の寸法によって種々異なると考えられる. 合理的, 経 済的な施工と残留応力および面外変形の低減効果の双方 を考慮して適切な入熱領域を決定する方法を検討寸る必 要があると言える.

本研究では 500×500×12 mm の鋼板を対象としたが，実 構造物では加熱領域外にも部材が連続する. 部材の非加 熱領域に熱が伝導する影響や，部材の非加熱領域による 力学的な拘束の影響が本研究における供試体の場合より も大きくなると予想される. また，本研究で用いた鋼板 の板厚 $(12 \mathrm{~mm})$ では, 板厚方向にほとんど温度差が生 じなかったが, より厚い鋼板の場合, 板厚方向の温度差 が生じやすくなるため，面外変形挙動に影響を与える可 能性がある. 今後は, 本研究で構築した手法を用いて実 構造物の形状，寸法，板厚などを変化させた解析を行い， 実構造物への溶接後熱処理の適用性を検討していく.

\section{5. 結言}

本研究では，主に薄い鋼板で構成される土木鋼構造物 の溶接後熱処理過程における応力および变形挙動の解明 を目的に，一連の基礎的実験および数值解析を行った. 得られた主な知見を以下に示す。

（1）溶接実験および熱弹塑性解析を行い，実験時の供 試体の温度履歴, 溶接変形, 溶接残留応力を高精 度に再現できる解析モデルを構築した。

(2) JIS Z 3700 に規定される条件下で溶接後熱処理実験 を行い，熱影響部の硬化が緩和され，金属組織が 微細化されたことを確認した。 また, 熱弾塑性解 析により熱処理実験をシミュレーションし, 溶接 ビード近傍において残留応力が緩和されたことを 確認した．一方，溶接ビード近傍以外では，熱処 理過程で残留応力が増加したことが分かった.

(3) 鋼板供試体に溶接後熱処理の温度履歴を与えると, 熱処理後に $0.03 \mathrm{~mm}$ 程度の残留変形が生じた. 一 方, 溶接供試体に溶接後熱処理の温度履歴を与え ると, 溶接ビード側, 溶接ビードの裏側いずれか ら加熱しても溶接変形と同じ傾向の変形が生じ, 溶接変形よりも $0.2 \mathrm{~mm}$ 程度大きな残留変形が生じ た.

（4）鋼板の一部の領域を局所的に加熱する熱処理条件 では，加熱過程および冷却過程における供試体の 面内方向の温度差がそれぞれ面外変形, 残留応力 を発生させる主要因子となることが分かった。

(5) 熱処理過程において生じる鋼板全体の残留応力と 面外変形の抑制を両立する手法として, 加熱範囲 を現行の局所熱処理条件よりも拡大寸る手法を提 案し，その有効性を示した. 
謝辞 : 本研究の一部は (一社) 日本溶接協会平成 28 年 度次世代を担う研究者助成事業を受けて実施した。本研 究の熱処理作業には JEMIX（株）平松慶大氏，重信敏 男氏の協力を賜った。ここに感謝の意を表す.

\section{参考文献}

1）国土交通省：インフラ長寿命化基本計画，インフラ 老朽化対策の推進に関する関係省庁連絡会議， $17 \mathrm{p}$ 2013.

2) 山田健太郎：鋼橋の長寿命化における塗替え塗装の 重要性-木曽川大橋の斜材の破断事故の教訓-, 橋 梁・鋼構造物塗装, Vol.36, No.1, pp.2-9, 2008.

3) 土木学会 鋼構造委員会 鋼構造の残存而荷性能評 価と耐久性向上方策研究小委員会 : 腐食した鋼構造 物の残存性能評価および性能回復技術，2007.

4) 田中甚吉 : 溶接後熱処理は何故必要か? , 溶接学会 誌，第 65 巻，第 3 号，pp.12-14，1996.

5) 鈴木宏, 岡田八郎, 橋本宏：圧力容器における PWHT の効果とその決定条件，溶接学会誌，第 61 巻第 6 号, pp.473-477, 1992

6) 平松卓也 : 溶接後熱処理（PWHT），熱処理，第 51 巻，第 6 号，pp. 332-337， 2011.

7）廣畑幹人，伊藤義人：簡易熱源を用いた熱処理によ るすみ肉まわし溶接継手の残留応力緩和に関する研 究，土木学会論文集 A1(構造・地震工学), Vol.71, No.2, pp. 208-220, 2015.

8）廣畑幹人，伊藤義人：荷重作用下における鋼部材へ
のあて板溶接で生じる残留応力および応力除去焼鈍 に関する研究，土木学会論文集 A2(応用力学), Vol.71, No.2（応用力学論文集 Vol.18）， pp. 773784, 2015

9）神戸製鋼株式会社 : 神戸製鋼溶接総合カタログ-溶接 材料・システム-軟鋼〜 $550 \mathrm{MPa}$ 級鋼（ソリッドワイ ヤ) MG-50T, 2016.

10）金 裕哲，李 在翼，猪瀬幸太郎：すみ肉溶接で生じ る面外変形の高精度予測, 溶接学会論文集, 第 23 巻, 第 3 号, pp.431-435, 2005.

11）中川弘文，鈴木弘之：鋼梁の崩壊温度，鋼構造文集, 第 6 巻，第 22 号，pp57-65，1996.

12）溶接学会：溶接・接合便覧 第 2 版，丸善出版, pp.1145-1146, 2003.

13）日本規格協会：溶接後熱処理方法 JIS Z 3700 -同解 説， 2009.

14）廣畑幹人，伊藤義人：トラフリブ溶接部の残留応力 緩和に対する簡易熱源による熱処理の適用性検討， 構造工学論文集，Vol.62A，2016.

15) Gayle, F.W., Fields, R.J., Luecke, W.E., Banovic, S.W., Foecke, T., McCowan, C.N., Siewert T.A. and McColskey, J.D.: Federal Building and Fire Safety Investigation of the World Trade Center Disaster: Mechanical and Metallurgical Analysis of Structural Steel, NIST NCSTAR 1-3, National Institute of Standards and Technology, 2005.

16）田中甚吉，小幡忠良：応力除去焼鈍に関する研究 （第 2 報），溶接学会誌，第 36 巻，第 3 号，pp.3642, 1967.

(2017.6. 23 受付) 


\section{EFFECT OF THERMAL HISTORY BY POST-WELD HEAT TREATMENT ON RESIDUAL STRESS RELAXATION AND DEFORMATION BEHAVIOR OF STEEL MEMBER}

\section{Hirotaka MORI and Mikihito HIROHATA}

When welding is considered as a joining method for repair and reinforcement of steel structures, welded joints have disadvantages such as influence of residual stress on fatigue strength and embrittlement of heat affected zone by welding heat input. Post-weld heat treatment is an effective method to solve these problems. However, civil steel structures assembled by thin plates are possible to be deformed easily by PWHT. For investigating residual stress change and deformation behavior of welded thin plates by PWHT, a series of experiment and analysis were carried out. A condition of PWHT for reducing residual stress and out-of plane deformation was proposed with considering generation mechanism of them. 